\title{
PHYSICAL AND CHEMICAL PROPERTIES OF SOILS IN DIFFERENT PHYSIOGRAPHIC ENVIRONMENTS IN THE SOUTHERN AMAZONAS REGION
}

\author{
ATRIBUTOS FÍSICOS E QUÍMICOS DE SOLOS EM DIFERENTES AMBIENTES \\ FISIOGRÁFICOS NA REGIÃO SUL DO AMAZONAS, BRASIL
}

\author{
Willian Barros NASCIMENTO' ${ }^{1}$; Milton César Costa CAMPOS $^{2}$; \\ Bruno Campos MANTOVANELLI ${ }^{3}$; Luís Antônio Coutrim dos SANTOS ${ }^{3}$; \\ José Mauricio CUNHA ${ }^{2}$; Igor Hister LOURENÇO ${ }^{4}$; Flávio Pereira de OLIVEIRA ${ }^{5}$ \\ 1. Colegiado de Engenharia Ambiental, Universidade Federal do Amazonas, Instituto de Educação Agricultura e Ambiente-IEAA, \\ Humaitá, AM, Brasil; 2. Colegiado de Agronomia, Universidade Federal do Amazonas, Instituto de Educação Agricultura e Ambiente- \\ IEAA, Humaitá, AM, Brasil; 3. Departamento de Ciências Rurais, Universidade Federal de Santa Maria, Santa Maria, RS, Brasil. \\ brunomantovanelli21@ gmail.com; 4. Graduando em Engenharia Agronômica, Universidade Federal do Amazonas, Instituto de \\ Educação Agricultura e Ambiente-IEAA, Humaitá, AM, Brasil; 5. Centro de Ciências Agrárias, Universidade Federal da Paraíba, Areia,
} $\mathrm{PB}$, Brasil.

\begin{abstract}
The Amazon region has a great diversity of landscapes such as forests galleries, natural fields ("Cerrados Amazônicos"), dense forest, these environments made possible the formation of a broad class of soils over time. The aim of this study was to evaluate the physical and chemical properties of soils in different physiographic environments in southern Amazonas, Brazil. Three areas of representative physiographies were selected, all of them in natural conditions: natural field / forest and floodplain / dry land transitions, and corrugated relief areas. Soil samples were collected in layers of 0.0 to 0.20 and $0.80-1.0 \mathrm{~m}$. From the samples collected the following physical analyzes were performed: particle size, bulk density, particle density, total porosity and saturated hydraulic conductivity; and chemical: exchangeable calcium, magnesium, aluminum and potassium available, phosphorus, potential acidity, $\mathrm{pH}$ and organic carbon. Based on the results of chemical analysis were calculated the sum of bases and base saturation. The results were submitted to multivariate statistics analysis, at the discretion of the principal component analysis (PCA). From the results it is clear that different physiographic environments studied influence the formation of different soil classes, featuring the diversity of Amazonian soils. The PCA allowed the distinction and formation of different similarity groups, thus enabling to relate the physical and chemical properties with the physiographic formation in which they are inserted.
\end{abstract}

KEYWORDS: Amazonian Soils. Multivariate Analysis. Soil Attributes.

\section{INTRODUÇÃO}

Soil types and their properties are results of interactions between formation factors and soil processes (JENNY, 1941; SIMONSON, 1959). Considering the internal spatial and temporal variability of these factors and processes, infinite types of soils with different properties can be formed. Studies have shown that topography is one of the most important factors influencing soils formation, especially in a regional level (WANG et al., 2009) and its effects are more pronounced on young soils (SEIBERT et al., 2007).

The Amazon region presents a wide diversity of landscapes such as gallery forests, natural fields ("Cerrados Amazônicos"), dense forest, corrugated and gently corrugated relief, generating environments which allowed the formation of many soil classes of over time
(CAMPOS et al., 2012a). One of the main characteristics of Amazonian soils is their chemical properties, mostly poor and with low natural fertility (with exception of Archaeological Dark Earths (ADEs).

On the other hand, the different reliefs, landscape forms, intensity and duration of the pedological processes and the source material characteristic determines the type and the distribution of the soil in the landscapes (WYECKI et al., 2005; MEIRELES et al., 2012), according to a logic related to the geomorphogenic and pedogenetic processes. Thus, understanding the relationship between "soil-landscape", a spatial pattern distribution of soil attributes and their dependence relationships with relief arrangement can be found, however, climatic conditions, geological features and hydrological aspects are fundamental to understanding these relationships 
(CAMPOS et al., 2011). According to Samouëlian \& Cornu (2008), the soil-landscape relations allow the analysis of these factors together, favoring a better geomorphic and landscape evolution processes understanding.

Studies developed by Martins et al. (2006); Campos et al. (2012a); Alho et al. (2014) and Alho et al. (2016) in native field environments "Campos de Puciari - Humaitá" in transition with forests, allow a general understanding of landscape variations in soil classes and the direct influence on physical and chemical attributes, as well as how the landscape associated with water movement, condition the soils in different classes, thus justifying the great variability found in these environments and in the Amazonian region. Another important physiographic environment found is the floodplain / dry land transitions, the floodplain are the areas that border the "muddy water" rivers, rich in suspended material and subject to seasonal flooding; while the dry land areas do not suffer flooding and are formed by tertiary sediments (CAMPOS et al., 2012b). As a rule, floodplains are fertilized by their continuous process from the deposition of allochthonous sediments (Andean) giving them greater natural fertility (CAMPOS et al. 2013).

In addition Campos et al. (2011) emphasizes that in this part of the Amazon it is common to find environments with soils in gently wavy to corrugated relief with different characteristics of the environments initially mentioned, the presence of granite and the variations of the relief favored the presence of dystrophic soils at the top Rhodic Ferralsol and eutrophic soils Typic Hapludox at the transport base.

In this way the different forms of representative landscapes in Amazonian region, such as the natural fields ("Cerrado"), floodplain / dry land transitions and other regions, present different soil classes, which, unfortunately, doesn't have much studies to correlate with the different landscapes, compromising the proper use and exploitation of these soils productive potential, as well as, managing them in a correct way reducing the degradation of these environments by disorganized agricultural and forestry practices. It's worth to mention that this part of the Amazon is inserted in the so-called "Deforestation Arc", (a stretch that stretches from Maranhão to Rondônia), an area where landscapes are being destroyed and soils lose their productive potential from a physical and chemical point of view, for the logging, opening of areas for agriculture or pasture for livestock, where forest burning is the most used process for deforestation (COHEN et al., 2007).

Thus, the objective of this study was to evaluate the physical and chemical attributes of soils under different physiographic environments in the southern Amazonas.

\section{MATERIAL AND METHODS}

\section{Physical Environment Characterization}

Three areas with southern Amazonas region representative physiographies were selected, all of them under natural conditions, according to the map presented (Figure 1).
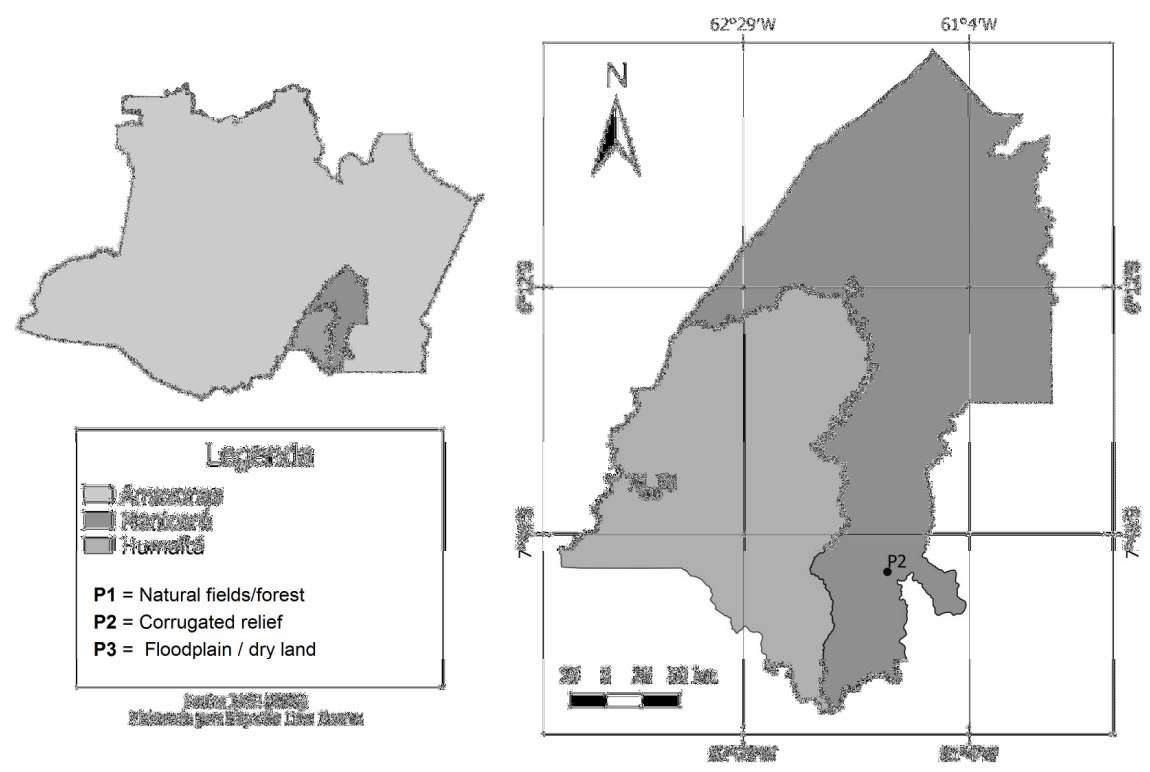

Figure 1. Location points of studied areas. 
The profiles sampled in the natural field environments "Campos de Puciari - Humaitá" are located in the 54 th Army Jungle Infantry Battalion and are characterized by field units separated from each other by forested areas or even cerrado, whose contacts are not always gradual, being settled on undifferentiated alluviums, which are chronologically derived from the Holocene. The sediments of this formation are derived from two sedimentation cycles: a) lower sandy banks, which represent pluvial-fluvial sedimentation and; b) upper clay sediments, indicating lacustrine sedimentation (BRAUN; RAMOS, 1959).

The areas in floodplain / dry land environments are located in the Humaitá National Forest, with approximately 468.79 hectares, the first area borders muddy water rivers, rich in suspended material and subject to seasonal flooding, while the second is not flooded and is formed from tertiary sediments. This area is under domain of transition between present Holocene and alluvial sediments of the Solimões formation, from Middle Pliocene Upper Pleistocene, with materials from continental, fluvial and lacustrine depositions (BRAZIL, 1978).

The other studied profiles are located in the community of Santo Antônio do Matupí, on BR 230 Transamazônica, municipality of Manicoré, Amazonas. They are located on Rondonian Granites characterized by the presence of granites, muscovite, biotite, adamelites and granodiorites of intrusive cratogenic origin, in the form of "stocks" and batholiths (BRAZIL, 1978).

The studied areas are located in the same climatic zone, according to Köppen, belonging to group A (Tropical Rainy Weather) and climatic type Am (monsoon rainfall), presenting a short dry period duration. The average annual rainfall is limited by the isoetes of 2,250 and $2,750 \mathrm{~mm}$, with a rainy period beginning in October and extending through June. Average annual temperatures range from 25 to $27{ }^{\circ} \mathrm{C}$ and the relative moisture between 85 and $90 \%$.

\section{Field and laboratory methodology}

Twelve representative profiles of the studied environments were selected, four in each environment (Table 1). Twenty lateral samples were collected from the representative profiles. The criterion of choice of depths was the coincidence with the superficial and subsurface diagnostic horizons, respectively the layers of $0.0-0.20 \mathrm{~m}$ and 0.80-1.0 m.

For the soils in floodplain / dry land sequence, the samples were collected on the three geomorphic surfaces established, according to the following description: Geomorphic surface I: top; Geomorphic surface II: upper third; Geomorphic surface III: high deposition foothill and low deposition foothill. In the natural field / forest transition area, the samples were collected by pedoenvironments: higher field; lower field; ecotone zone and forest. In the transitions under corrugated relief, samples were collected in the different segments of identified slopes: higher top; half slope; transport foothill and lower top. Soils were classified according to Embrapa (2013) and Soil Taxonomy (SOIL SURVEY STAFF, 2010).

Table 1. Sampling points, physiography, municipality, soil class and sampling sites coordinates in the southern Amazonas region.

\begin{tabular}{|c|c|c|c|}
\hline Profile & Soil Classes & Municipality & Location \\
\hline \multicolumn{4}{|c|}{ Natural field / Forest, Humaitá - AM } \\
\hline P1 & Cambissolo Háplico Alítico plíntico (Typic Distropepts) & Humaitá-AM & $\begin{array}{l}07^{\circ} 30^{\prime} 22,6^{\prime \prime} \mathrm{S} \\
63^{\circ} 04^{\prime} 57,3 " \mathrm{~W}\end{array}$ \\
\hline $\mathrm{P} 2$ & Gleissolo Háplico Alítico típico (Typic Fluvaquents) & Humaitá-AM & $\begin{array}{l}07^{\circ} 30^{\prime} 16,3 " \mathrm{~S} \\
61^{\circ} 04^{\prime} 57,3^{\prime \prime} \mathrm{W}\end{array}$ \\
\hline P3 & $\begin{array}{c}\text { Cambissolo Háplico Alítico gleissólico (Typic } \\
\text { Distropepts) }\end{array}$ & Humaitá-AM & $\begin{array}{l}07^{\circ} 29^{\prime} 59,0^{\prime \prime} \mathrm{S} \\
63^{\circ} 04^{\prime} 50,0^{\prime \prime} \mathrm{W}\end{array}$ \\
\hline P4 & Argissolo Vermelho Alítico plíntico (Typic Paleudalf) & Humaitá-AM & $\begin{array}{l}07^{\circ} 29^{\prime} 55,1^{\prime \prime} \mathrm{S} \\
63^{\circ} 04^{\prime} 51,3 " \mathrm{~W}\end{array}$ \\
\hline \multicolumn{4}{|c|}{ Corrugated relief, Manicoré - AM } \\
\hline P5 & Latossolo Vermelho Distrófico típico. (Rhodic Ferralsol). & Manicoré-AM & $\begin{array}{l}07^{\circ} 59^{\prime} 58,8^{\prime \prime} \mathrm{S} \\
61^{\circ} 34^{\prime} 27,7^{\prime \prime} \mathrm{W}\end{array}$ \\
\hline P6 & $\begin{array}{c}\text { Argissolo Vermelho-Amarelo Distrófico abruptíco (Typic } \\
\text { Haplohumult). }\end{array}$ & Manicoré-AM & $\begin{array}{l}07^{\circ} 59^{\prime} 51,6^{\prime \prime} \mathrm{S} \\
61^{\circ} 34^{\prime} 36,7^{\prime \prime} \mathrm{W}\end{array}$ \\
\hline P7 & $\begin{array}{c}\text { Latossolo Vermelho-Amarelo Eutrófico típico (Typic } \\
\text { Hapludox). }\end{array}$ & Manicoré-AM & $\begin{array}{l}07^{\circ} 59^{\prime} 54,8^{\prime \prime} \mathrm{S} \\
61^{\circ} 34^{\prime} 46,4^{\prime \prime} \mathrm{W}\end{array}$ \\
\hline
\end{tabular}




\begin{tabular}{|c|c|c|c|}
\hline P8 & $\begin{array}{l}\text { Latossolo Vermelho-Amarelo Distrófico típico (Typic } \\
\text { Hapludox). }\end{array}$ & Manicoré-AM & $\begin{array}{l}07^{\circ} 59^{\prime} 56,2^{\prime \prime} \mathrm{S} \\
61^{\circ} 34^{\prime} 51,5^{\prime \prime} \mathrm{W}\end{array}$ \\
\hline \multicolumn{4}{|c|}{ Floodplain / dry land, Humaitá - AM } \\
\hline P9 & Latossolo Amarelo Distrófico plíntico (Typic Kandiudox). & Humaitá-AM & $\begin{array}{l}7^{\circ} 30 ’ 22^{\prime \prime} \mathrm{S} \\
63^{\circ} 011^{\prime}, \mathrm{W}\end{array}$ \\
\hline P10 & $\begin{array}{c}\text { Latossolo Amarelo Distrófico argissólico (Typic } \\
\text { Kandiudox). }\end{array}$ & Humaitá-AM & $\begin{array}{c}7^{\circ} 30^{\prime} 22^{\prime \prime} \mathrm{S} \\
63^{\circ} 011^{\prime} 15^{\prime} \mathrm{W}\end{array}$ \\
\hline P11 & Neossolo Flúvico Ta Eutrófico típico (Typic Haplaquents). & Humaitá-AM & $\begin{array}{l}7^{\circ} 30 ’ 22^{\prime} " \mathrm{~S} \\
63^{\circ} 011^{\prime}, 15^{\prime} \mathrm{W}\end{array}$ \\
\hline P12 & $\begin{array}{c}\text { Neossolo Flúvico Ta Eutrófico gleissólico (Typic } \\
\text { Haplaquents). }\end{array}$ & Humaitá-AM & $\begin{array}{c}7^{\circ} 30^{\prime} 22^{\prime \prime} \mathrm{S} \\
63^{\circ} 011^{\prime} 15^{\prime \prime} \mathrm{W}\end{array}$ \\
\hline
\end{tabular}

The particle size analysis (silt, clay and sand) was performed by the pipette method, using $0.1 \mathrm{NaOH}$ mol L-1 solution as a chemical dispersant and mechanical stirring in low speed apparatus for $16 \mathrm{~h}$ using a soil dispersion mixer Wagner type. The clay fraction was separated by sedimentation, the coarse and fine sand by sieving and silt calculated by difference (DONAGEMA et al., 2017).

Undisturbed structure samples were collected in soil core, with mean content of 98.36 $\mathrm{cm}^{3}$, in the depth of $0.0-0.20 \mathrm{~m}$. The samples were prepared by removing the excess soil from its ends, then saturated by raising a water slide in an aluminum tray until it reached $2 / 3$ of the height of the soil core.

The total porosity was obtained by the saturation method, in which the relation between the saturation moisture and the respective soil volume represents the total porosity. The soil density was determined from undisturbed samples using volumetric rings collected in the horizons, obtained by the soil mass ratio in the drying oven at $105^{\circ} \mathrm{C}$ and the ring volume according to Donagema et al. (2017) methodology.

And the particle density determined by the volumetric flask method, according to the methodology described by Flint \& Flint (2002). The saturated hydraulic conductivity (Ksat) was determined from the constant loading method as described by Donagema et al. (2017), and calculated according to Darcy's law and expressed in $\mathrm{cm} \mathrm{h}^{-1}$.

The $\mathrm{pH}$ was determined potentiometrically using 1: 2.5 ratio of soil: in water and $\mathrm{KCl}$. Exchangeable calcium, magnesium and aluminum were extracted by $\mathrm{KCl} 1 \mathrm{~mol} \mathrm{~L}^{-1}$ and the potential acidity $(\mathrm{H}+\mathrm{Al})$ extracted with buffered calcium acetate solution at $\mathrm{pH}$ 7.0. Potassium and phosphorus were extracted with Mehlich-1 solution (DONAGEMA et al., 2017). Based on the results of the chemical analyzes, the sum of bases (SB), cation exchange capacity (CEC) and base saturation (V\%) were calculated. The organic carbon (OC) was determined by the wet oxidation method, by external heating (YEOMANS; BREMNER, 1988).

The data were submitted to the principal component analysis (PCA), aiming to summarize the values obtained from the studied attributes of the different environments. In this way, the initial set of 18 variables was characterized by two new latent variables (PC1 and PC2), which allowed its location in two-dimensional figures (ordering of accesses by principal components). The adequacy of this analysis is verified by the total information of the original variables, retained in the principal components that show eigenvalues greater than unity, or lower eigenvalues without relevant information. All multivariate statistical analyzes were processed in STATISTICA software version 7.0 (STATSOFT, 2004).

\section{RESULTS AND DISCUSSION}

\section{Physical attributes}

In relation to the sampled profiles, for the granulometric fractions in the different physiographic environments, the dominance of silt fraction was observed in almost all the profiles (Table 2). In natural field / forest transition environments this behavior of silt dominance is common due to the alluvial nature of the sediments that compose the source material Brazil (1978), similar results were also obtained by Martins et al. (2006) and Campos et al. (2011) studying natural fields. It was observed that the clay content tends to increase from the high relief to floodplain / dry land physiographies. According to Lima et al. (2006), this behavior can be attributed to the recent sedimentary nature, since the soils of these environments are closely related to the source material, quantity of sediments from the Andean and sub-Andean regions, transported by the rivers and deposited in the alluvial plain. Campos et al. (2012b); Campos et al. (2013); Alho et al. (2014) and Alho et al. (2016) studying floodplain / dry land environments and natural field / forest transitions 
also found high levels of silt in these environments, thus indicating the sedimentary nature of these soils, what commonly occur in these environments.

The silt/clay ratio is commonly used as an auxiliary index to indicate the degree of soil weathering, so the higher the value of this ratio, the less weathered the soil (JACOMINE, 2005). The silt / clay ratio in the studied profiles presented high values in the Inceptisols and Entisols, indicating their less degree of weathering. This relationship in the Oxisols and Ultisols was very low, thus characterizing the higher degree of weathering of these soils, being therefore strongly related to its location in the physiographic landscape and geoenvironmental characteristics that favored the weathering process of these soils according to the time, cause the high precipitations and temperatures of this region favor the greater weathering of these soils, corroborating with Santos et al. (2012) who studied a transition under alluvial terraces in the region of the middle Madeira River.
The bulk density (BD) presented similar behavior in the studied physiographies, always being superior in the subsurface layer (Table 2). The values presented a variation of 0.86 to $1.30 \mathrm{~g} \mathrm{~cm}^{-3}$ in the superficial layer and 0.99 to $1.65 \mathrm{~g} \mathrm{~cm}^{-3}$ in subsurface. The Inceptisols in the natural field / forest physiography presented the highest $\mathrm{BD}$ indexes, being this factor not associated to the possible stage of soil compaction, but to the density increase that occurs due to the processes of clay eluviation to the subsurface layers, these results corroborate with Campos et al. Al. (2010); Campos et al. (2011) and Mantovanelli et al. (2015) which studied natural fields and geomorphic surfaces in the southern Amazonas region. The total porosity presented differences in both surface and subsurface layers, showing high values in the natural field / forest and floolplain / dry land (Table 2), also coinciding in environments with higher organic matter content, thus corroborating with results obtained by Campos et al. (2011) who studied soils in the Manicoré region, AM.

Table 2. Physical soils characterization in different physiographic environments in southern Amazonas region.

\begin{tabular}{|c|c|c|c|c|c|c|c|c|c|c|}
\hline \multirow{2}{*}{ Perfil } & \multirow{2}{*}{ Class } & \multirow{2}{*}{$\begin{array}{l}\text { Depth } \\
\text { m }\end{array}$} & Sand & Silt & Clay & $\mathrm{S} / \mathrm{C}$ & $\mathrm{BD}$ & PD & $\mathrm{TP}$ & Ksat \\
\hline & & & \multicolumn{3}{|c|}{--------g kg-1------- } & & \multicolumn{2}{|c|}{$---\mathrm{g} \mathrm{cm}^{-3}---$} & $\mathrm{m}^{3} \mathrm{~m}^{-3}$ & $\mathrm{~cm} \mathrm{~h}^{-1}$ \\
\hline \multicolumn{11}{|c|}{ Natural Field / Forest, Humaitá - AM } \\
\hline \multirow{2}{*}{1} & \multirow{2}{*}{ Inceptisol } & $0.0-0.2$ & 239.8 & 614.3 & 145.9 & 4.21 & 1.30 & 2.63 & 0.50 & 1.03 \\
\hline & & $0.8-1.0$ & 238.7 & 479.9 & 281.4 & 1.70 & 1.49 & 2.63 & 0.43 & 0.05 \\
\hline \multirow{2}{*}{2} & \multirow{2}{*}{$\begin{array}{l}\text { Entisol } \\
\text { (Gleysol) }\end{array}$} & $0.0-0.2$ & 96.2 & 688.0 & 215.8 & 3.18 & 0.86 & 2.44 & 0.65 & 1.94 \\
\hline & & $0.8-1.0$ & 34 & 529.5 & 436.5 & 1.21 & 1.65 & 2.70 & 0.39 & 0.00 \\
\hline \multirow{2}{*}{3} & \multirow{2}{*}{ Inceptisol } & $0.0-0.2$ & 274.9 & 595.9 & 129.2 & 4.61 & 1.05 & 2.60 & 0.59 & 1.04 \\
\hline & & $0.8-1.0$ & 308.3 & 200.7 & 491.0 & 0.40 & 1.55 & 2.60 & 0.40 & 0.05 \\
\hline \multirow{2}{*}{4} & \multirow{2}{*}{ Ultisol } & $0.0-0.2$ & 66.0 & 736.7 & 197.3 & 3.73 & 1.02 & 2.60 & 0.61 & 3.12 \\
\hline & & $0.8-1.0$ & 49.4 & 705.2 & 245.4 & 2.87 & 1.46 & 2.63 & 0.45 & 0.59 \\
\hline \multicolumn{11}{|c|}{ Corrugated relief, Manicoré - AM } \\
\hline \multirow{2}{*}{5} & \multirow{2}{*}{ Oxisol } & $0.0-0.2$ & 223.3 & 478.8 & 297.9 & 1.60 & 1.06 & 2.70 & 0.61 & 36.57 \\
\hline & & $0.8-1.0$ & 184.8 & 269.6 & 545.6 & 0.49 & 0.99 & 2.78 & 0.64 & 5.63 \\
\hline \multirow{2}{*}{6} & \multirow{2}{*}{ Ultisol } & $0.0-0.2$ & 231.0 & 546.8 & 222.2 & 2.45 & 1.29 & 2.70 & 0.52 & 9.68 \\
\hline & & $0.8-1.0$ & 536.9 & 0.7 & 462.4 & 0.001 & 1.30 & 2.70 & 0.52 & 5.89 \\
\hline \multirow{2}{*}{7} & \multirow{2}{*}{ Oxisol } & $0.0-0.2$ & 598.9 & 177.7 & 223.4 & 0.79 & 1.38 & 2.70 & 0.49 & 9.54 \\
\hline & & $0.8-1.0$ & 364.9 & 265.0 & 370.1 & 0.71 & 1.39 & 2.67 & 0.48 & 8.14 \\
\hline \multirow{2}{*}{8} & \multirow{2}{*}{ Oxisol } & $0.0-0.2$ & 255.2 & 120.0 & 624.8 & 0.19 & 1.27 & 2.67 & 0.52 & 7.41 \\
\hline & & $0.8-1.0$ & 174.3 & 322.0 & 503.7 & 0.63 & 1.12 & 2.70 & 0.58 & 2.86 \\
\hline \multicolumn{11}{|c|}{ Floodplain / Dry land, Humaitá - AM } \\
\hline \multirow[t]{2}{*}{9} & \multirow{2}{*}{ Oxisol } & $0.0-0.2$ & 347.3 & 490.6 & 162.0 & 3.02 & 1.12 & 2.70 & 0.58 & 2.86 \\
\hline & & $0.8-1.0$ & 121.8 & 784.7 & 93.5 & 8.39 & 1.45 & 2.56 & 0.43 & 0.00 \\
\hline \multirow[t]{2}{*}{10} & \multirow{2}{*}{ Oxisol } & $0.0-0.2$ & 499.1 & 316.8 & 184.1 & 1.72 & 1.06 & 2.56 & 0.59 & 1.26 \\
\hline & & $0.8-1.0$ & 681.6 & 190.1 & 128.3 & 1.48 & 1.56 & 2.67 & 0.41 & 1.24 \\
\hline \multirow[t]{2}{*}{11} & Fnticl & $0.0-0.2$ & 16.9 & 472.9 & 510.2 & 0.92 & 1.06 & 2.50 & 0.58 & 0.00 \\
\hline & HIIISOI & $0.8-1.0$ & 6.0 & 609.8 & 384.2 & 1.58 & 1.45 & 2.67 & 0.46 & 0.10 \\
\hline 12 & Entic & $0.0-0.2$ & 12.3 & 659.1 & 328.6 & 2.00 & 1.02 & 2.82 & 0.64 & 0.00 \\
\hline & Entisol & $0.8-1.0$ & 1.1 & 859.4 & 139.5 & 6.16 & 1.15 & 2.78 & 0.59 & 0.00 \\
\hline
\end{tabular}

$\mathrm{BD}=$ Bulk Density; PD = Particle Density; TP = Total Porosity; Ksat = Saturated soil hidraulic conductivity; S/C = Silt / Clay ratio. 
It was observed that for the Oxisols, the predominant class in the studied physiographies, the hydraulic conductivity values (Ksat) ranged from 9.54 to $36.57 \mathrm{~cm} \mathrm{~h}^{-1}$, showing a trend of reduction with depth. For the Ultisols, the Ksat values ranged from 0.59 to $9.68 \mathrm{~cm} \mathrm{~h}^{-1}$, showing reduction with the depth increase, which may be related to the process of clay accumulation in deeper horizons, common in these soils. For the Inceptisols, the values ranged from 0.05 to $1.05 \mathrm{~cm} \mathrm{~h}^{-1}$, the highest values being favored by the silt texture.

\section{Chemical Attributes}

The $\mathrm{pH}$ values $\left(\mathrm{H}_{2} \mathrm{O}\right)$ in all physiographic environments showed a similar trend ranging from 2.4 to 5.2, with these indexes being higher in natural field / forest and corrugated relief environments. In this sense all $\mathrm{pH}$ values are considered low, indicating greater limitations to the agricultural crop as Farjado et al. (2009) and Campos et al. (2013) emphasizes, thus reflecting the natural condition of acid Amazonian soils.

The TOC contents were more expressive in the floodplain / dry land physiography, especially in the Entisols classes. High carbon values were found in the first soil layers $(0.0-0.2 \mathrm{~m})$ ranging from 24.97 to $89.92 \mathrm{~g} \mathrm{~kg}^{-1}$. Although there was reduction with the depth increase (19.40 to $18.45 \mathrm{~g} / \mathrm{kg}-1)$. Longo \& Espíndola (2000) and Magalhães et al. (2013) observed that the occurrence of the most pronounced reduction of the superficial layer to the subsurface is normal or expected, since it is related to the greater surface deposition of vegetal and animal residues, as well as the superficial nature of the roots in the floodplain areas. In relation to the Entisols, Portugal (2009) explains that there is usually a delay in the process of decomposition of organic matter during a period of the year, due to the seasonal floods, justifying the low levels of carbon in depth.

The exchangeable $\mathrm{Ca}^{2+}, \mathrm{Mg}^{2+}$ and $\mathrm{K}^{+}$ contents (Table 2), especially $\mathrm{Ca}^{2+}$, was more expressive in floodplain / dry land physiography. Alfaia et al. (2007); Magalhães et al. (2013) and Campos et al. (2013) found similar $\mathrm{Ca}$ values in Entisol to those reported in this study, varying from 24.7 to $12.4 \mathrm{cmolc} \mathrm{kg}^{-1}$. The higher relative contents of $\mathrm{Ca}$ found in this environment are favored directly by the richness of the sedimented material and the richness of the material that favors its deposition (Campos et al., 2010). The exchangeable $\mathrm{Al}^{3+}$ contents were more expressive in natural field / forest and floodplain / dry land environments, as observed in the Entisols (Gleysols) and Entisols, being these associated with the higher O.C contents. On the other hand, phosphorus levels (P) (Table 2) were more expressive in floodplain / dry land physiography, especially in the Entisol $0.0-0.20 \mathrm{~m}$ layer, with values ranging from 11.19 to $19.70 \mathrm{mg}$ $\mathrm{kg}^{-1}$. Lima et al. (2006) and Campos et al. (2013) find high levels of $\mathrm{P}$ in floodplain environments, associating these indexes with the topography that favors the deposition and accumulation of nutrients from the floods of the Madeira River, in this lower position of the landscape. The other physiographies presented low values of $\mathrm{P}$, being these disadvantaged by the high $\mathrm{Al}^{3+}$ levels that occur in these environments, and due to the raised relief position that favors the leaching of this element in the landscape.

It was observed that the sum of bases (SB) was less expressive in the corrugated relief physiography when compared to the other environments, this fact is possibly due to the more stable position of this environment that conditions more leaching of exchangeable cations and variation in the contents of this component (CARRÉ \& MCBRATNEY, 2005). In the floodplain / dry land environment, this behavior is a contribution product coming from adjacent areas, as this is a geomorphic environment of materials deposition (CAMPOS et al. 2012b; CAMPOS et al. 2013), as suggested by Park and Burt (2002) which highlight the topographic aspects as important indicators of soil properties variation at the local level.

The cation exchange capacity (CEC) in both studied layers in the different physiographies presented different behavior, with more expressive values in the floodplain / dry land. This high CTC behavior in floodplain environments is mainly due to the qualitie of the waters that flood these areas, since they are muddy waters, originating from Andean sediments, they provide these soils better chemical quality. Campos et al. (2010) and Magalhães et al. (2013) both studying floodplain environments found high CEC rates in these soils in Amazonian environments.

For base saturation (V\%), it was verified that all the studied profiles presented values between $2 \%$ and $79 \%$, thus evidencing the low fertility from the upper soils, with the high values presented in floodplains, justifying the soils fertility in these environments. These lower values confer the dystrophic character found frequently by authors studying Amazonian region soils (CAMPOS et al., 2012a; SANTOS et al., 2012; MARTINS et al., 2006). 
Table 3. Chemical characterization of soils under different physiographic environments in the southern Amazonas region.

\begin{tabular}{|c|c|c|c|c|c|c|c|c|c|c|c|c|c|}
\hline \multirow[t]{2}{*}{ Perfi } & \multirow[t]{2}{*}{ Class } & Depth & $\begin{array}{c}\mathrm{pH} \\
\mathrm{H}_{2} \mathrm{O}\end{array}$ & $\mathrm{Ca}^{2+}$ & $\mathrm{Mg}^{2+}$ & $\mathrm{K}^{+}$ & $\mathrm{P}$ & $\mathrm{Al}^{3+}$ & $\mathrm{H}+\mathrm{Al}$ & SB & CEC & V & $\mathrm{OC}$ \\
\hline & & $\mathrm{m}$ & & \multicolumn{3}{|c|}{------cmolc kg-1------ } & \multicolumn{2}{|c|}{$\mathrm{mg} \mathrm{kg}^{-1}$} & \multicolumn{3}{|c|}{------cmolc kg ${ }^{-1}------$} & \multirow[t]{2}{*}{$\%$} & \multirow{2}{*}{$\mathrm{g} \mathrm{kg}^{-1}$} \\
\hline \multicolumn{12}{|c|}{ Natural Field / Forest, Humaitá - Am } & & \\
\hline \multirow[t]{2}{*}{1} & \multirow{2}{*}{ Inceptisol } & $0.0-0.2$ & 4.6 & 0.1 & 0.03 & 0.07 & 0.92 & 3.1 & 5.6 & 0.3 & 7.2 & 3.5 & 26.14 \\
\hline & & $0.8-1.0$ & 5.2 & 0.1 & 0.00 & 0.04 & 0.26 & 6.0 & 8.3 & 0.2 & 10.7 & 2.0 & 19.34 \\
\hline \multirow[t]{2}{*}{2} & \multirow{2}{*}{ Entisol (Gleysol) } & $0.0-0.2$ & 4.4 & 0.2 & 0.03 & 0.07 & 0.61 & 2.7 & 9.9 & 0.4 & 14.9 & 2.5 & 36.71 \\
\hline & & $0.8-1.0$ & 5.1 & 0.2 & 0.77 & 0.04 & 0.13 & 9.3 & 10.1 & 2.8 & 20.9 & 13.1 & 18.45 \\
\hline \multirow[t]{2}{*}{3} & \multirow{2}{*}{ Inceptisol } & $0.0-0.2$ & 3.9 & 0.2 & 0.13 & 0.07 & 0.33 & 3.1 & 7.0 & 0.3 & 11.7 & 4.9 & 24.97 \\
\hline & & $0.8-1.0$ & 2.4 & 0.2 & 0.01 & 0.04 & 0.26 & 5.3 & 7.5 & 0.2 & 12.4 & 2.3 & 19.40 \\
\hline \multirow[t]{2}{*}{4} & \multirow{2}{*}{ Ultisol } & $0.0-0.2$ & 4.5 & 0.2 & 0.14 & 0.16 & 0.48 & 4.5 & 10.9 & 16.6 & 16.6 & 3.2 & 32.91 \\
\hline & & $0.8-1.0$ & 4.9 & 0.1 & 0.03 & 0.04 & 0.18 & 5.4 & 8.1 & 19.1 & 18.9 & 1.3 & 19.85 \\
\hline \multicolumn{14}{|c|}{ Corrugated Relief, Manicoré - Am } \\
\hline \multirow[t]{2}{*}{5} & \multirow{2}{*}{ Oxisol } & $0.0-0.2$ & 4.0 & 0.1 & 0.1 & 0.1 & 0.33 & 1.7 & 13.2 & 0.3 & 11.1 & 14.0 & 40.0 \\
\hline & & $0.8-1.0$ & 4.6 & 0.2 & 0.0 & 0.0 & 0.26 & 0.6 & 6.4 & 0.3 & 4.8 & 9.0 & 30.54 \\
\hline \multirow[t]{2}{*}{6} & \multirow{2}{*}{ Ultisol } & $0.0-0.2$ & 4.4 & 0.2 & 0.2 & 0.1 & 0.82 & 0.6 & 5.0 & 1.5 & 4.6 & 34.0 & 28.85 \\
\hline & & $0.8-1.0$ & 5.2 & 0.2 & 0.3 & 0.0 & 0.89 & 0.4 & 1.7 & 1.0 & 2.2 & 44.0 & 21.25 \\
\hline \multirow[t]{2}{*}{7} & \multirow{2}{*}{ Oxisol } & $0.0-0.2$ & 3.9 & 0.1 & 0.1 & 0.1 & 1.57 & 1.7 & 3.3 & 0.8 & 2.1 & 37.0 & 28.00 \\
\hline & & $0.8-1.0$ & 4.5 & 0.2 & 0.0 & 0.0 & 1.37 & 1.7 & 3.4 & 1.3 & 2.5 & 51.0 & 19.60 \\
\hline \multirow[t]{2}{*}{8} & \multirow{2}{*}{ Oxisol } & $0.0-0.2$ & 3.7 & 0.1 & 0.1 & 0.1 & 3.43 & 2.5 & 8.4 & 0.8 & 2.1 & 37.0 & 29.40 \\
\hline & & $0.8-1.0$ & 4.7 & 0.2 & 0.0 & 0.0 & 1.64 & 0.9 & 3.3 & 1.3 & 2.5 & 51.0 & 23.05 \\
\hline \multicolumn{14}{|c|}{ Floodplain / Dry Lands, Humaitá - Am } \\
\hline \multirow[t]{2}{*}{9} & \multirow{2}{*}{ Oxisol } & $0.0-0.2$ & 3.4 & 0.5 & 0.2 & 0.1 & 0.18 & 3.4 & 13.8 & 1.0 & 9.5 & 11.0 & 89.92 \\
\hline & & $0.8-1.0$ & 3.9 & 0.4 & 0.2 & 0.0 & 026 & 4.8 & 8.0 & 0.8 & 5.2 & 17.0 & 79.68 \\
\hline 10 & Oxicol & $0.0-0.2$ & 3.4 & 0.7 & 0.5 & 0.1 & 0.70 & 4.8 & 11.2 & 1.6 & 9.2 & 18.0 & 26.56 \\
\hline & UXISOI & $0.8-1.0$ & 3.9 & 0.4 & 0.3 & 0.0 & 0.26 & 3.3 & 4.4 & 0.9 & 6.8 & 13.0 & 19.52 \\
\hline 11 & Enticol & $0.0-0.2$ & 3.8 & 12.8 & 2.5 & 0.2 & 19.70 & 4.6 & 12.8 & 15.9 & 21.6 & 74.0 & 87.04 \\
\hline & Eilusor & $0.8-1.0$ & 4.2 & 11.7 & 1.2 & 0.1 & 4.80 & 3.2 & 7.7 & 13.4 & 19.0 & 71.0 & 83.52 \\
\hline 12 & & $0.0-0.2$ & 4.0 & 10.2 & 0.8 & 0.1 & 11.19 & 7.1 & 16.5 & 11.4 & 18.3 & 63.0 & 86.72 \\
\hline & Entisol & $0.8-1.0$ & 4.5 & 31.0 & 1.1 & 0.1 & 4.53 & 8.4 & 16.3 & 32.4 & 41.1 & 79.0 & 75.20 \\
\hline
\end{tabular}

$\mathrm{Ca}^{2+}=$ calcium; $\mathrm{Mg}^{2+}=$ magnesium; $\mathrm{K}^{+}=$potassium; $\mathrm{P}=$ phosphorus; $\mathrm{Al}^{3+}=$ exchangeable aluminum; $\mathrm{H}+\mathrm{Al}=$ potential acidity; $\mathrm{SB}=$ sum of bases; $\mathrm{CEC}=$ cation exchange capacity; $\mathrm{V}=$ base saturation; $\mathrm{OC}=$ organic carbon.

\section{Principal Component Analysis - PCA}

In order to evaluate the interaction between physical and chemical attributes with the studied physiographies profiles, the principal component analysis (PCA) was used (Figure 2). The PCA confirmed the results presented for the characterization of profiles (Table 2 and Table 3). It was observed in the surface (Figure 2A) and subsurface layers (Figure 2B) that the profiles were divided into three and four groups respectively, in other words, there was a similarity association among the studied environments, thus indicating the pattern of similarity between the different profiles studied.

The first group formed by the profiles P11 and P12 in the superficial layer (Figure 2A), reflect the greater association with variables related to soil fertility, this pattern is due to the physiographic characteristics of these environments associated with Entisols, which condition the high soils fertility, being under the theory that the flood with waters of Andean origin and sediments give to these soils the greater deposition / retention of nutrients.

The second group formed by the profiles P1, P3, P5, P6, P7, P8 and P9, characterizes the similarity in the natural field / forest and the corrugated relief environments for the sand, Ksat and BD variables. In this group the Ksat and BD variables, associated to these environments reflect the higher soil wear degree in these sites, the slope topography favors the greater variation of soils hydraulic conductivity, leading to a higher percolation of water in its profile, while the high $\mathrm{BD}$, is associated to the Natural Fields due to the high clay and silt contents that cause the densification due to pore clogging (Martins et al., 2006; Mantovanelli et al., 2015). The third group formed by P2 and P4, reflect the high levels of silt and acidity in natural field / forest environments, 
which is a typical condition found for these environments.

In the subsurface layer (Figure 2B), it was observed that there was a distribution similar to the surface layer, with the exception of the formation of four groups, the highest expression being in relation to the environments of Field / Forest and Floodplain / Dry Lands in the sand, But this behavior does not condition marked expressions in the behavior of these environments.
In the subsurface layer (Figure 2B), it was observed that there was a distribution similar to the surface layer, with exception of four groups formation, with the highest expression being in relation to the natural field / forest and floodplain / dry land environments for the sand indexes, but this behavior does not condition marked expressions in these environments behavior.
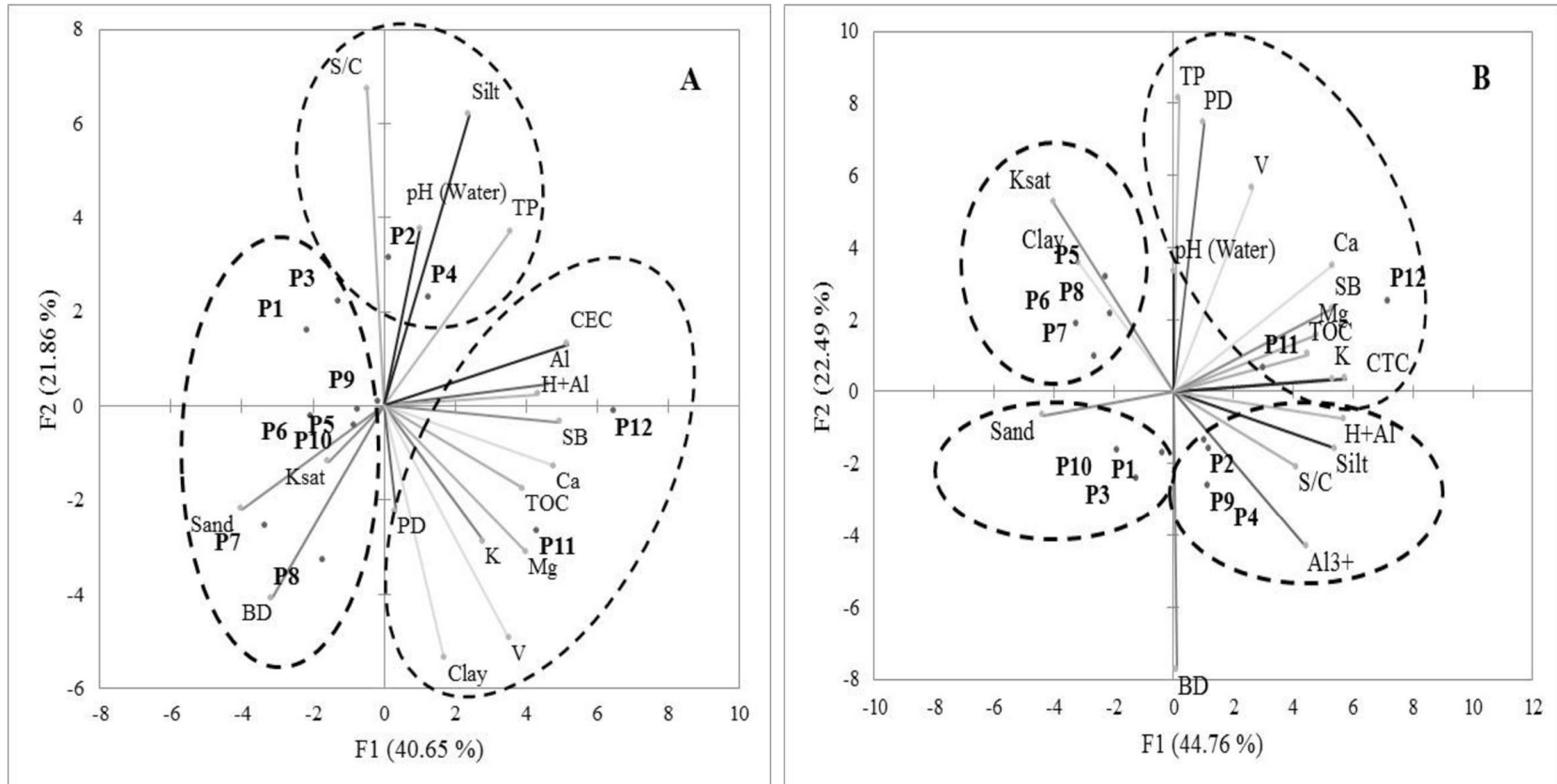

Figure 2. Principal Component Analysis of soils under different physiographic environments in the southern Amazonas region. $\mathrm{A}=$ Surface layer; $\mathrm{B}=$ subsurface layer.

\section{CONCLUSIONS}

The different physiographies condition the soil physical and chemical attributes different characteristics, characterizing the great diversity of soils presented in the Amazonian region presents according to physiographic variations.
The principal component analysis allowed the grouping of similarity between the soils in the different studied environments, making possible to make inferences between the relationship between the environments and the soils.

RESUMO: A região amazônica possui uma grande diversidade de paisagens, como galerias de florestas, campos naturais (Cerrados Amazônicos), floresta densa, possibilitando a formação de uma ampla classe de solos ao longo do tempo. O objetivo deste estudo foi investigar as propriedades físicas e químicas de solos em diferentes ambientes fisiográficos no sul do Amazonas, Brasil. Três áreas de fisiografias representativas foram selecionadas, todas em condições naturais: campo natural / floresta e transições de várzea / terra firme e áreas de relevo corrugado. Amostras de solo foram coletadas em camadas de 0,0 a 0,20 e 0,801,0 m. Das amostras coletadas foram realizadas as seguintes análises físicas: tamanho de partícula, densidade do solo, densidade de partículas, porosidade total e condutividade hidráulica saturada; e químico: cálcio trocável, magnésio, alumínio e potássio disponíveis, fósforo, acidez potencial, $\mathrm{pH}$ e carbono orgânico. Com base nos resultados da análise química foram calculados a soma das bases e saturação por bases. Os resultados foram submetidos à análise estatística multivariada, a critério da análise de componentes principais (PCA). A 
partir dos resultados, percebe-se que diferentes ambientes fisiográficos estudados influenciam a formação de diferentes classes de solos, caracterizando a diversidade de solos amazônicos. O PCA permitiu a distinção e formação de diferentes grupos de similaridade, permitindo relacionar as propriedades físico-químicas com a formação fisiográfica em que estão inseridos.

PALAVRAS - CHAVE: Solos da Amazônia. Análise multivariada. Atributos do solo.

\section{REFFERENCES}

ALFAIA, S.S.; NEVES, A.L.; RIBEIRO, G. DE A.R.; FAJARDO, J.D.V.; UGUEN, K.; AYRES, M.I. da C. Características Químicas dos solos de várzea em diversos sistemas de uso da terra ao longo da calha dos rios Solimões-Amazonas. In: NODA, S.N. (Org.). Agricultura familiar na Amazônia das águas. Manaus: EDUA, 2007.

ALHO, L. C.; CAMPOS, M. C. C.; SILVA, D. M. P.; MANTOVANELLI, B. C.; SOUZA, Z. M. Variabilidade espacial da estabilidade de agregados e estoque de carbono em Cambissolo e Argissolo. Pesquisa Agropecuária Tropical, Goiânia, v. 44, n. 2, p. 246-254, 2014. https://doi.org/10.1590/S198340632014000300001

ALHO, L. C.; CAMPOS, M. C. C.; MANTOVANELLI, B. C.; SILVA, D. M. P.; SOUZA, Z. M.; CUNHA, J. M.; RODRIGUES, M. D. Physical and geospatial attributes of inceptisols and ultisols under native vegetation in Humaitá, AM, Brazil. Bioscience Journal, Uberlandia, v. 32, n. 1, p. 422-430, 2016.

https://doi.org/10.14393/BJ-v32n2a2016-32656

BADÍA, D.; MRTÍ, C.; AZNAR, J.M.; LEÓN, J. Influence of slope and parent rock on soil genesis and classification in semiarid mountainous environments. Geoderma, Amsterdam, v. 193-194, n. 2, p. 13-21, 2013. https://doi.org/10.1016/j.geoderma.2012.10.020

BRASIL. Ministério das Minas e Energia. Projeto Radam Brasil, folha SB. 20, Purus. Rio de Janeiro, 1978. $561 \mathrm{p}$.

BRAUN, E. H. G.; RAMOS, J. R. A. Estudo agroecológico dos campos Puciari-Humaita (Estado do Amazonas e Território Federal de Rondônia). Revista Brasileira de Geografia, v. 21, p. 443-497, 1959.

CAMPOS, M. C. C. Pedogeomorfologia aplicada a ambientes amazônicos do médio Rio Madeira. Tese (Doutorado em Ciência do Solo). 242 f. Recife: Universidade Federal Rural de Pernambuco; 2009.

CAMPOS, M. C. C.; RIBEIRO, M. R.; SOUZA JÚNIOR, V. S.; RIBEIRO FILHO, M. R.; COSTA, E. U. C. Segmentos de vertente e atributos do solo de uma topossequência na região de Manicoré, AM. Ciência Agronômica, Fortaleza, v. 41, n. 4, p. 501-510, 2010. https://doi.org/10.1590/S1806-66902010000400001

CAMPOS, M. C. C.; RIBEIRO, M. R.; SOUZA JÚNIOR, V. S, RIBEIRO FILHO, M. R, SOUZA, R. V. C. Relações solo-paisagem em uma topossequência sobre substrato granítico em Santo Antônio do Matupi, Manicoré (AM). Revista Brasileira de Ciência do Solo, Viçosa, v. 35, n. 1, p. 13-23, 2011. https://doi.org/10.1590/S0100-06832011000100002

CAMPOS, M. C. C.; RIBEIRO, M. R.; SOUZA JÚNIOR, V. S.; RIBEIRO FILHO, M. R.; ALMEIDA M. C. Topossequência de solos na transição Campos Naturais-Floresta na região de Humaitá, Amazonas. Acta Amazônica, Manaus, v. 42, n. 3, p. 387-398, 2012a. https://doi.org/10.1590/S0044-59672012000300011

CAMPOS, M. C. C.; RIBEIRO, M. R.; SOUZA JÚNIOR, V.; RIBEIRO FILHO, M. R.; ALMEIDA, M. C. Relações Solo-Superfície Geomórfica em uma Topossequência Várzea-Terra Firme na Região de Humaitá (AM). Revista Brasileira de Ciência do Solo, Viçosa, v. 36, n. 2, p. 325-336, 2012 b. https://doi.org/10.1590/S0100-06832012000200002 
CAMPOS, M. C. C.; RIBEIRO, M. R.; SOUZA JÚNIOR, V. S.; RIBEIRO FILHO, M. R.; AQUINO, R. E.; OLIVEIRA, I. A. Superfícies geomórficas e atributos do solo em uma topossequência de transição VárzeaTerra Firme. Bioscience Journal, Uberlandia, v. 29, p.132-142, 2013.

CARRÉ, F.; MCBRATNEY, A. B. Digital terron mapping. Geoderma, Amsterdam, v. 128, n. 3-4, p. 340-353, 2005. https://doi.org/10.1016/j.geoderma.2005.04.012

COHEN, J. C. P.; BELTRÃO, J. C.; GANDU, A. W.; SILVA, R. R. Influência do desmatamento sobre o ciclo hidrológico na Amazônia. Ciência Cultura, São Paulo, v. 59, n. 3. p. 36-39, 2007.

DONAGEMA, G. K., CAMPOS, D. V. B., CALDERANO, S. B., TEIXEIRA, W. G., VIANA J. H. M. Manual de métodos de análise de solo. Rio de Janeiro: Embrapa Solos, 2017, 514p.

FAJARDO, J. D. V.; SOUZA, L. A. G.; ALFAIA, S. S. Características químicas de solos de várzeas sob diferentes sistemas de uso da terra, na calha dos rios baixo Solimões e médio Amazonas. Acta Amazônica, Manaus. v. 39, n. 4, p. 731-740. 2009. https://doi.org/10.1590/S0044-59672009000400001

FLINT, A. L, FLINT, L. E. Particle density. In: DANE, J. H.; TOPP. G. C. (Ed.). Methods of soil analysis. Soil Science Society of America, v. 4, p. 229-240, 2002.

JACOMINE, P. K. T. Origem e evolução dos conceitos e definições de atributos, horizontes diagnósticos e das classes de solos do Sistema Brasileiro de Classificação de Solos (SiBCS). In: VIDAL-TORRADO, P.; ALLEONI, L. R. F.; COOPER, M.; SILVA, A. P.; CARDOSO, E. J., eds. Tópicos em ciência do solo. Viçosa, MG, Sociedade Brasileira de Ciência do Solo, 2005. v. 4. p. 193-231.

JENNY, H. Factors of soil formation: A system of quantitative pedology. New York, McGraw Hill, 1941. 279 p.

LIMA, H. N.; MELLO, J. W. V.; SCHAEFER, C. E. G. R.; KER, J. C., LIMA, A. M. N. Mineralogia e química de três solos de uma topossequência da Bacia Sedimentar do Alto Solimões, Amazônia Ocidental. Revista Brasileira de Ciência do Solo, Viçosa, v. 30, n. 1, p. 59-68, 2006. https://doi.org/10.1590/S010006832006000100007

LONGO, R. M.; ESPÍNDOLA, C. R. Alterações em características químicas de solos da região Amazônica pela introdução de pastagens. Acta Amazônica, Manaus, v. 30, n. 1, p. 71-80, 2000.

https://doi.org/10.1590/1809-43922000301080

MAGALHÃES, R. C.; GOMES, R. C. M. Mineralogia e química de solo de várzea e suas susceptibilidades no processo de terras caídas na comunidade do Divino Espírito Santo - AM. Sociedade e Natureza, Uberlândia, v. 25, n. 3, p. 609-621, 2013. https://doi.org/10.1590/S1982-45132013000300013

MANTOVANELLI, B. C.; SILVA, D. A. P.; CAMPOS, M. C. C.; GOMES, R. P.; SOARES, M. D. R.; SANTOS, L. A. C. Avaliação dos atributos do solo sob diferentes usos na região de Humaitá, Amazonas. Revista de Ciências Agrarias, Belém, v. 58, n. 2, p. 122-130, 2015 https://doi.org/10.4322/rca.1822

MARTINS, G. C.; FERREIRA, M. M.; CURI, N.; VITORINO, A. C. T.; SILVA, M. L. N. Campos nativos e matas adjacentes da região de Humaitá (AM): atributos diferencias dos solos. Ciência e Agrotecnologia, Lavras, v. 30, n. 2, p. 221-227, 2006. https://doi.org/10.1590/S1413-70542006000200005

MEIRELES, H. T.; MARQUES JÚNIOR, J.; CAMPOS, M. C. C.; PEREIRA, G. T. Relações solo-paisagem em topossequência de origem basáltica. Pesquisa Agropecuária Tropical, Goiania, v. 42, n. 2, p. 129-136, 2012. https://doi.org/10.1590/S1983-40632012000200001 
PARK, S. J.; BURT, T. P. Identification and characterization of pedogeomorphological processes on a hillslope. Soil Science Society American Journal, Madison, v. 66, n. 6, p. 1897- 1910, 2002. https://doi.org/10.2136/sssaj2002.1897

PORTUGAL, A. F. Geoambientes de terra firme várzea da Região do Juruá, Noroeste do Acre. Tese (Doutorado em Solos e Nutrição em Plantas), Faculdade de Agronomia, Universidade Federal de Viçosa, Minas Gerais, 2009.

SAMOUËLIAN, A.; CORNU, S. Modelling the formation and evolution of soils, towards an initial synthesis. Geoderma, Amsterdam, v. 145, n. 3-4, p.401-409, 2008. https://doi.org/10.1016/j.geoderma.2008.01.016

SANTOS, L. A. C.; CAMPOS, M. C. C.; COSTA, H. S.; PEREIRA, A. R. Caracterização de solos em uma topossequência sob terraços aluviais na região do médio rio Madeira (AM). Ambiência, Parana, v. 8, p. 319331, 2012. https://doi.org/10.5777/ambiencia.2012.02.07

SEIBERT, J.; STENDAHL, J.; SØRENSEN, R. Topographical influences on soil properties in boreal forests. Geoderma, Amsterdam.,v. 141, n. 1-2, p. 139-148, 2007. https://doi.org/10.1016/j.geoderma.2007.05.013

SIMONSON, R. W. Outline of a generalized theory of soil genesis. Soil Science Society American Journal, Madison, v. 23, p. 152-156, 1959. https://doi.org/10.2136/sssaj1959.03615995002300020021x

SOIL SURVEY STAFF. Keys to soil taxonomy. 11, ed. Washington: United States Department of Agriculture. Natural Resources Conservation Service. 2010. 338p.

STATSOFT. Statistica 7.0. Tulsa: StatSoft, 2004.

WANG, H. J.; SHI, X. Z.; YU, D. S.; WEINDORF, D. C.; HUANG, B.; SUN, W. X. ; MILNE. E. Factors determining soil nutrient distribution in a small-scaled watershed in the purple soil region of Sichuan Province, China. Soil Tillage Research, Madison, v. 105, n. 2, p. 300-306, 2009.

https://doi.org/10.1016/j.still.2008.08.010

WYSOCKI, D. A.; SCHOENEBERGER, P. J.; LAGARRY, H. E. Soil surveys: a window to the subsurface. Geoderma, Amsterdam. v. 126, n. 1-2, p. 167-180, 2005. https://doi.org/10.1016/j.geoderma.2004.11.012

YEOMANS, J. C.; BREMNER, J. M. A rapid and precise method for routine determination of organic carbon in soil. Communication in Soil Science and Plant Analysis. v. 19, n. 13, p. 1467-1476, 1988. https://doi.org/10.1080/00103628809368027 